\title{
UBEZPIECZENIA SPOŁECZNE PRACOWNIKÓW MIEJSKICH ZARZĄDU MIASTA LUBLINA W LATACH 1918-1939
}

\section{WPROWADZENIE}

Argumentem przemawiającym za podjęciem rozważań dotyczących ubezpieczeń społecznych pracowników miejskich Zarządu m. Lublina w okresie II Rzeczypospolitej jest brak opracowania dotykającego tej tematyki. Wskazać należy, że poruszany temat mieści się $\mathrm{w}$ szerszej problematyce statusu formalnoprawnego urzędników miejskich okresu międzywojennego, która do tej pory także nie doczekała się kompleksowego omówienia ${ }^{1}$. W niniejszym artykule przedstawione zostaną zasady podlegania pracowników lubelskiego Magistratu pierwszym przepisom ubezpieczeniowym, obowiązującym w odrodzonej Polsce. Szczególnej analizie poddane będą przepisy wewnętrzne Zarządu $\mathrm{m}$. Lublina w zakresie ubezpieczania pracowników miejskich na wypadek choroby oraz zabezpieczenia emerytalnego.

$\mathrm{Na}$ ziemiach polskich po odzyskaniu niepodległości istniały różne systemy prawne odziedziczone po zaborcach ${ }^{2}$. Odmienny stan prawny obowiązywał także w dziedzinie ubezpieczeń społecznych. W chwili odzyskania niepodległości najbardziej rozwinięty system ubezpieczeń występował w b. zaborze pruskim. Nieco

Mgr Mariola SzewczaK-Daniel - asyst w Katedrze Historii Państwa i Prawa, Instytut Nauk Prawnych, Wydział Prawa i Administracji, Uniwersytet Marii Curie-Skłodowskiej w Lublinie, Plac Marii Curie Skłodowskiej 5, 20-031 Lublin; e-mail: mariola.szewczak@poczta.umcs.lublin.pl; https:// orcid.org/0000-0001-6245-2211

${ }^{1}$ Zarys opracowania statusu formalnoprawnego pracowników znajduje się w opracowaniach: K. SŁowIŃsKi, Kancelaria miasta Radomia w latach 1915-1939, Lublin: Wydawnictwo KUL 2016, s. 76-101; J. KoRCZAK, Sytuacja prawna pracowników samorzadowych w II i III Rzeczypospolitej, [w:] 20 lat samorzadu terytorialnego w II i III Rzeczypospolitej, red. J. Korczak, Wrocław: Kolonia Limited 2010, s. 379-404.

${ }^{2}$ A. Кововоwicz, W. Wiткоwsкi, Historia ustroju i prawa polskiego (1772-1918), Kraków: Zakamycze 2001, s. 291; Historia państwa i prawa Polski 1918-1939, cz. II, red. F. Ryszka, Warszawa: Polskie Wydawnictwo Naukowe 1968, s. 260-261. 
gorzej kwestia ta przedstawiała się $\mathrm{w}$ b. zaborze austriackim, zaś $\mathrm{w}$ b. zaborze rosyjskim ubezpieczenia społeczne praktycznie nie funkcjonowały ${ }^{3}$. W Lublinie, jako mieście należącym do dawnego zaboru rosyjskiego, nie istniały żadne instytucje ubezpieczeniowe, zaś ewentualne ubezpieczenie na wypadek choroby oraz zabezpieczenie emerytalne pracowników należało do pracodawcy. Podobnie brak było ubezpieczenia na wypadek niezdolności do pracy, natomiast ubezpieczenie od nieszczęśliwych wypadków ograniczono do osób zatrudnionych w przemyśle 4 .

\section{ZASADY UBEZPIECZENIA PRACOWNIKÓW ZARZĄDU M. LUBLINA NA PODSTAWIE USTAWY Z DNIA 19 MAJA 1920 R. O OBOWIĄZKOWYM UBEZPIECZENIU NA WYPADEK CHOROBY}

Pierwszym znaczącym krokiem, zmierzającym do ujednolicenia ubezpieczeń społecznych pracowników, poprzez organizację lecznictwa ubezpieczeniowego, po odzyskaniu niepodległości, było wejście w życie ustawy z 19 maja $1920 \mathrm{r}$. o obowiązkowym ubezpieczeniu na wypadek choroby ${ }^{5}$. Ustawa ta w rozwiązaniach nawiązywała do Dekretu Naczelnika Państwa z 11 stycznia 1919 r. o takim samym tytule, który praktycznie nie wszedł w życie ${ }^{6}$. Ustawa, powołując do życia Kasy Chorych, utworzyła bardzo postępowy system ubezpieczenia chorobowego, oparty na zasadach: powszechności, przymusu, terytorialności oraz samorządności ${ }^{7}$.

Przymusem ubezpieczenia objęte zostały wszystkie osoby utrzymujące się z pracy najemnej, bez względu na rodzaj umowy o pracę ${ }^{8}$. Obowiązek ubezpieczenia dotyczył również pracowników samorządowych. Wysokość składki ubezpieczenia wynosiła $6,5 \%$ płacy, przy czym pracodawca pokrywał $3 / 5$, zaś pracownik - od-

${ }^{3}$ Zob. W. SzUBert, Stulecie polskich instytucji ubezpieczenia społecznego, „Studia i Materiały z Historii Ubezpieczeń Społecznych w Polsce" 7 (1989), s. 5.

4 [brak informacji o Autorze] O ubezpieczeniu społecznym w Polsce, „Praca i Opieka Społeczna” 1 (1923) s. 38-45.

${ }^{5}$ Ustawa z dnia 20 maja 1920 r. o obowiązkowym ubezpieczeniu na wypadek choroby, Dz. U. $\mathrm{Nr} 44$, poz. 272[dalej cyt.: ustawa o obowiązkowym ubezpieczeniu na wypadek choroby].

${ }^{6}$ Dekret z dnia 11 stycznia 1919 r. o obowiązkowym ubezpieczeniu na wypadek choroby, Dz. Pr. P. P. Nr 9, poz. 122.

${ }^{7}$ J. SAdowsKa, Prawnoorganizacyjne podstawy ubezpieczenia na wypadek choroby $w$ Polsce, „Studia i Materiały z Historii Ubezpieczeń Społecznych w Polsce” 9 (1993), s. 18; T. ZIELIŃsKi, Ubezpieczenia społeczne pracowników. Zarys systemu prawnego - część ogólna, Warszawa-Kraków: Wydawnictwo Naukowe PWN 1994, s. 43; J. WratnY, Organizacja ubezpieczeń Spolecznych, [w:] Rozwój ubezpieczeń społecznych w Polsce, red. C. Jackowiak, Wrocław: Zakład Narodowy im. Ossolińskich, Wydawnictwo Polskiej Akademii Nauk 1991, s. 53-55.

${ }^{8}$ W. Muszalski, Ubezpieczenia społeczne. Zarys ogólny, cz. 1, Warszawa: Zakład Ubezpieczeń Społecznych 1984, s. 35. 
powiednio $2 / 5$ składki $^{9}$. Świadczenia przyznawane osobom ubezpieczonym obejmowały: bezpłatną pomoc lekarską, lekarstwa, środki opatrunkowe oraz zasiłki pieniężne za dni nieobecności z powodu choroby. Pomoc lekarska przysługiwała ubezpieczonemu przez 26 tygodni, począwszy od pierwszego dnia choroby ${ }^{10}$. Zasiłek chorobowy wynosił $60 \%$ zarobku, gdy zaś pracownik posiadający rodzinę przebywał w szpitalu, wypłacano zasiłek domowy w wysokości $40 \%$ płacy ${ }^{11}$.

Jeszcze przed wejściem w życie rzeczonej ustawy, Zarząd miasta Lublina zorganizował dla swoich pracowników pomoc lekarską, utrzymywaną całkowicie przez miasto. Ulgowa pomoc lekarska dla pracowników miejskich została wprowadzona, począwszy od 1 listopada 1917 r., na mocy uchwały Rady Miejskiej z dnia 11 października $1917 \mathrm{r}$. i Magistratu z 22 października tego roku ${ }^{12}$. W myśl powziętej uchwały mogli korzystać z niej wszyscy pracownicy Magistratu z pensją poniżej $1200 \mathrm{rb}$ rocznie wraz z rodziną, do której zaliczono małżonka oraz małoletnie dzieci $^{13}$. Ulgowa pomoc wyrażała się w konieczności pokrycia przez pracownika zaledwie niewielkiej części kosztów leczenia - Magistrat dopłacał odpowiednio: za poradę udzieloną $\mathrm{w}$ domu -3 kor., za poradę na mieście -6 kor., przy czym porady udzielone w nocy opłacano w podwójnej wysokości. Pomoc lekarska obejmowała poradę lekarską w gabinecie lekarza, poradę lekarską w domu chorego, leczenie szpitalne oraz zaopatrzenie w lekarstwa oraz niezbędne środki lecznicze. Pracownicy chcący skorzystać z ulgowej porady lekarskiej otrzymywali od kierowników poszczególnych wydziałów biuletyny uprawniające do przyjęcia takiej pomocy. Każdy biuletyn składał się z dwóch odcinków, z których jeden pozostawał u lekarza, zaś na drugim lekarz wypisywał receptę do apteki ${ }^{14}$. Zasady udzielania pomocy lekarskiej uległy zmianie w związku z wejściem w życie ustawy o obowiązkowym ubezpieczeniu na wypadek choroby ${ }^{15}$. Chodziło bowiem o dostosowanie zakresu świadczeń do zabezpieczenia na wypadek choroby, przewidzianego w ustawie. $\mathrm{W}$ rezultacie przeprowadzonych zmian system zabezpieczenia pracowników

${ }^{9}$ D. JAKuBIEC, Pierwsze polskie instytucje ubezpieczeń spolecznych. Zarys historii i ustroju, Warszawa: Zakład Ubezpieczeń Społecznych 2007, s. 28.

${ }^{10}$ P. MaKarzec, Ubezpieczenia społeczne w II Rzeczypospolitej, „Zeszyty Naukowe WSEI”, seria Administracja 2 (2012), s. 201-202.

${ }^{11}$ JaKUBIEC, Pierwsze polskie instytucje, s. 28.

${ }^{12}$ Archiwum Państwowe w Lublinie [dalej cyt.: APL], Akta m. Lublina 1918-1939 [dalej cyt.: AmL 1918-1939], sygn. 401, Pismo Zarządu Miejskiego m. Lublina w Lublinie do Ubezpieczalni Społecznej z 6 stycznia 1937 r., k. 81.

${ }^{13}$ APL, AmL 1915-1918, sygn. 9, Komunikat Biura Prasowego w sprawie pomocy lekarskiej dla pracowników Magistratu m. Lublina, k. 9.

${ }^{14}$ Tamże.

15 APL, AmL 1918-1939, sygn. 503, Pismo Magistratu m. Lublina z 19 lutego 1925 r. do Ministerstwa Pracy i Opieki Społecznej w Warszawie, k. 66. 
miejskich na wypadek choroby oferowany przez Magistrat był korzystniejszy dla pracowników, aniżeli ten przewidziany ustawą.

Po wejściu w życie ustawy o obowiązkowym ubezpieczeniu na wypadek choroby na terenie kraju zaczęły się tworzyć Powiatowe Kasy Chorych, zrzeszające pracowników podlegających obowiązkowemu ubezpieczeniu. W Lublinie Powiatowa Kasa Chorych rozpoczęła działalność w dniu 10 marca 1924 r., obejmując zasięgiem cały powiat lubelski ${ }^{16}$. Jeszcze przed formalnym rozpoczęciem działalności, Komisarz Powiatowej Kasy Chorych w Lublinie, pismem z dnia 6 marca 1924 r., wezwał wszystkich pracodawców do zgłoszenia zatrudnionych przez nich pracowników do dnia 15 marca 1924 r. ${ }^{17}$ Magistrat m. Lublina od samego początku bardzo niechętnie ustosunkował się do rozwiązań ustawy, nakładającej przymus ubezpieczania pracowników samorządowych. Jeszcze tego samego dnia podjął uchwałe o nieprzystępowaniu do Powiatowej Kasy Chorych w związku z posiadaniem własnej organizacji pomocy lekarskiej, zabezpieczającej pracowników na wypadek choroby ${ }^{18}$. W piśmie adresowanym do Związku Miast Polskich tak motywował swoje stanowisko: „W ciągu całego okresu istnienia samorządu, Magistrat $\mathrm{m}$. Lublina $\mathrm{w}$ trosce o dobro wszystkich swych pracowników bez względu na rodzaj zatrudnienia i wysokość płacy zarobkowej zorganizował dla nich i ich rodzin bezpłatną, na koszt miasta, pomoc lekarską w bardzo szerokim zakresie oraz zapewnił świadczenie na wypadek śmierci i niezdolności do pracy"19. W dalszej części wywodów Magistrat wskazał, że przewaga przyjętego modelu udzielania świadczeń pracownikom miejskim, wynikała z faktu, iż dotychczas pracownicy miejscy posiadali wybór lekarzy wszelkich specjalności, zaś porada lekarska była im udzielana natychmiast bez względu na porę dnia, czego nie mogła zapewnić Kasa Chorych $^{20}$. Dodatkowo, świadczenie na wypadek śmierci pracownika wypłacano w wysokości 300\% jego miesięcznych poborów, a w razie niezdolności do pracy, w wysokości $100 \%$ przez okres sześciu miesięc ${ }^{21}$. Rozpatrując sprawę ubezpieczenia z punktu widzenia interesów samorządu Magistrat m. Lublina zaakcentował, że nałożony ustawą o obowiązkowym ubezpieczeniu na wypadek choroby, przymus ubezpieczeniowy dotkliwie godził $\mathrm{w}$ interesy samorządu i ,rujnował zamierzenia

\footnotetext{
${ }^{16}$ APL, AmL 1918-1939, sygn. 503, Komunikat o rozpoczęciu działalności Powiatowej Kasy Chorych w Lublinie, k. 2.

${ }^{17}$ APL, AmL 1918-1939, sygn. 503, Ogłoszenie Komisarza Powiatowej Kasy Chorych w Lublinie $z$ dnia 6 marca 1924 r., k. 9.

${ }^{18}$ APL, AmL 1918-1939, sygn. 503, Odpis uchwaty Magistratu m. Lublina z 6 marca 1924 r., k. 17.

19 APL, AmL 1918-1939, sygn. 503, Pismo Magistratu m. Lublina do Zwiazku Miast Polskich., k. 30 .

20 Tamże.

${ }^{21}$ Tamże, k. 31.
} 
sanacyjne miasta przez niepomierny i niemający pokrycia budżetowego wydatek na opłatę składki ubezpieczeniowej, której wysokość przewyższałaby blisko dwudziestokrotnie dotychczasowe koszta $\mathrm{z}$ tego tytułu"22.

Co więcej, Magistrat $\mathrm{m}$. Lublina postulował wprowadzenie do ustawy zmian. Poza wnioskiem o zniesienie przymusu ubezpieczenia w Kasie Chorych dla instytucji, gwarantujących swym pracownikom pomoc lekarską, Magistrat domagał się zmniejszenia opłat na rzecz Kas Chorych do maksimum 3\% od sumy zarob$\mathrm{ku}$, wprowadzenia indywidualnego leczenia chorych przez system biuletynowy, uwzględniający wolny wybór lekarzy ${ }^{23}$. W odpowiedzi na zgłoszony przez Magistrat m. Lublina memoriał, Minister Pracy i Opieki Społecznej odmówił przeprowadzenia nowelizacji ustawy, podkreślając przy tym, że należyte unormowanie spraw lecznictwa pracowników było możliwe tylko na zasadach, na których opierała się ustawa o obowiązkowym ubezpieczeniu na wypadek choroby ${ }^{24}$. Minister wskazał, że ubezpieczenia na wypadek choroby w innych instytucjach ubezpieczeniowych nie zwalniały z obowiązku należenia do Kasy Chorych ${ }^{25}$. W związku z powyższym, w opinii Ministra Pracy i Opieki Społecznej, uchwała władz miejskich nie mogła wpłynąc na stosunek do Kasy Chorych pracowników instytucji i przedsiębiorstw miejskich, których obowiązek ubezpieczenia nie podlegał dyskusji wobec wyraźnego brzmienia art. 3 ustawy o obowiązkowym ubezpieczeniu na wypadek choroby $^{26}$. Co się tyczyło natomiast obniżenia wysokości pobieranych składek, Minister podkreślił, że składki mogłyby być obniżone tylko po wnikliwym zbadaniu stanu finansowego kas miejskich w razie stwierdzenia, że przewyższały ustawowo przewidziane wydatki na ten cel $^{27}$.

Nieprzejednana postawa lubelskiego Magistratu, odmawiającego podporządkowaniu się wielokrotnym wezwaniom ze strony Komisarza Powiatowej Kasy Chorych, jak i Wojewody Lubelskiego, doprowadziła do wieloletniego sporu, który w końcu znalazł swój finał na drodze sądowej ${ }^{28}$. Mimo oddalenia skargi przez Sąd, Zarząd $\mathrm{m}$. Lublina nie podporządkował się przymusowi zgłoszenia pracowników do Kasy Chorych, kontynuując świadczenie ulgowej pomocy lekarskiej we własnym zakresie. W tym celu zrewidował nieco dotychczasowe zasady,

\footnotetext{
22 Tamże.

${ }^{23}$ APL, AmL 1918-1939, sygn. 503, Odpis uchwaty Rady Miejskiej m. Lublina z dnia 20 listopada 1924 r., k. 174.

${ }^{24}$ APL, AmL 1918-1939, sygn. 503, Pismo Ministerstwa Pracy i Opieki Spolecznej do Magistratu m. Lublina z 21 lutego 1925 r., k. 67.

${ }^{25}$ Tamże.

${ }^{26}$ Tamże.

27 Tamże.

28 APL, AmL 1918-1939, sygn. 503, Skarga Magistratu m. Lublina do Sadu Okręowego z 23 czerwca 1926 r., k. 103-104.
} 
wydając w dniu 30 czerwca 1930 r. Statut organizacyjny pomocy lekarskiej dla pracowników miejskich miasta Lublina ${ }^{29}$. Statut ten uzyskał akceptację Kierownika Zarządu miejskiego m. Lublina w dniu 14 lipca 1930 r. Uprawnienia do korzystania z pomocy lekarskiej pracownika Magistratu m. Lublina oraz członków jego rodziny, wstępnych, zstępnych, rodzaj pomocy lekarskiej, czas jej trwania oraz wszelkie świadczenia związane z lecznictwem i wypłatą zasiłków pieniężnych za czas niezdolności do pracy wskutek choroby były uregulowane zgodnie $\mathrm{z}$ ustawą o obowiązkowym ubezpieczeniu na wypadek choroby. Rozszerzeniu uległ krąg członków rodziny pracownika, którzy mogli skorzystać z pomocy lekarskiej. Uprawnionymi członkami rodziny byli: małżonkowie, zstępni, wstępni, bracia, siostry, wychowańcy oraz dzieci nieślubne, o ile zamieszkiwali wspólnie z pracownikiem, utrzymywali się wyłącznie z jego zarobku, nie podlegali przymusowi ubezpieczeniowemu, a także nie byli dobrowolnie ubezpieczeni ${ }^{30}$. Z pomocy mogli skorzystać także niemieszkający z pracownikiem żona i dzieci, jeżeli otrzymywały od niego alimenty ${ }^{31}$. W zakres pomocy lekarskiej wchodziła bezpłatna pomoc lekarska, rozpoczynająca się od pierwszego dnia choroby i trwająca - o ile choroba wcześniej się nie zakończyła - maksymalnie 26 tygodni $^{32}$. Pomoc lekarską oparto na zasadzie wyboru lekarza, spośród tych z którymi Zarząd miasta zawarł odpowiednie umowy ${ }^{33}$. Zgodnie $\mathrm{z}$ regulacjami nowego Statutu, pracownicy nie byli zobowiązani do pokrywania nawet części kosztów leczenia, które w całości uiszczał Magistrat m. Lublina ${ }^{34}$. W czasie trwania choroby i związanej z nią niezdolności do pracy, pracownik miejski otrzymywał pełne pobory służbowe maksymalnie przez 39 tygodni, zaś w drodze wyjątku za zezwoleniem Zarządu miasta - przez 52 tygodnie ${ }^{35}$. Pracownik otrzymujący za czas choroby pełne wynagrodzenie nie mógł występować do Zarządu miasta o przyznanie innych świadczeń pieniężnych, ponieważ w wynagrodzeniu tym mieścił się już zasiłek za czas trwania choroby i niezdolności do pracy, wynoszący $60 \%$ płacy ustawowej ${ }^{36}$. Pracownicy wydzielonych przedsiębiorstw miejskich oraz członkowie ich rodzin, otrzymywali pomoc lekarską na tych samych zasadach co pracownicy Magistratu.

${ }^{29}$ Dziennik Zarządu m. Lublina nr 9 i 10 z 21 października 1930 r., Statut organizacyjny pomocy lekarskiej dla pracowników miejskich miasta Lublina [dalej cyt.: Statut organizacyjny pomocy lekarskiej z 1930 r.], s.790-792.

${ }^{30}$ Art. 33 ustawy o obowiązkowym ubezpieczeniu na wypadek choroby.

${ }^{31}$ Tamże.

${ }^{32}$ Art. 22 ustawy o obowiązkowym ubezpieczeniu na wypadek choroby.

${ }^{33} \S 6$ Statutu organizacyjnego pomocy lekarskiej z 1930 r.

34 Tamże, § 1.

${ }^{35}$ Tamże, $\S 3$.

${ }^{36}$ Tamże, $\S 4$. 
Warto podkreślić, że problem uchylania się od obowiązku ubezpieczania pracowników samorządowych dotyczył także innych miast byłej Kongresówki. Trudności $\mathrm{z}$ wprowadzeniem $\mathrm{w}$ życie ustawy wynikały niewątpliwie $\mathrm{z}$ braku tradycji ubezpieczeniowych na tym obszarze. W tym samym czasie ubezpieczania pracowników samorządowych w Kasie Chorych odmówiły samorządy miast, które znajdowały się pod zaborem pruskim oraz austriackim, gdzie wdrażanie przepisów ustawy o obowiązkowym ubezpieczeniu na wypadek choroby przebiegało sprawnie, jak np. samorządy Torunia czy Wadowic ${ }^{37}$.

\section{ZASADY UBEZPIECZENIA PRACOWNIKÓW ZARZĄDU M. LUBLINA NA PODSTAWIE ROZPORZĄDZENIA Z DNIA 24 LISTOPADA 1927 R. O UBEZPIECZENIU PRACOWNIKÓW UMYSŁOWYCH}

Zmianę sytuacji prawnej w zakresie ubezpieczeń emerytalnych przyniosło wejście w życie w dniu 1 stycznia 1928 r. długo wyczekiwanego rozporządzenia Prezydenta Rzeczypospolitej Polski z dnia 24 listopada 1927 r. o ubezpieczeniu pracowników umysłowych ${ }^{38}$. Przepis art. 5 pkt 6 rozporządzenia wyłączył pracowników komunalnych spod jego działania, o ile pracownicy ci posiadali zabezpieczenie emerytalne, zapewnione w inny sposób ${ }^{39}$. W związku z tym poszczególne związki komunalne przystąpiły do opracowywania statutów o zaopatrzeniu emerytalnym swoich pracowników. Komisja emerytalna m. Lublina miała więc do wyboru: tymczasowe ubezpieczenie w zakładzie ubezpieczeń pracowników miejskich, którzy praw emerytalnych nie posiadali (w 1928 r. - 4414 osób) lub też przyznanie pracownikom tym od dnia 1 stycznia 1928 r. uprawnienia emerytalnego, nie mniejszego od przysługującego funkcjonariuszom państwowym ${ }^{40}$. Władze miejskie wybrały to drugie wyjście, które było korzystniejsze dla pracowników, jak i miasta ${ }^{41}$.

Do czasu uchwalenia statutu o zaopatrzeniu emerytalnym pracowników gminy m. Lublina, Rada Miejska w dniu 22 listopada 1928 r. na wniosek Magistratu, podjęła uchwałę przyznającą prawa emerytalne członkom Zarządu miasta i wszystkim

\footnotetext{
${ }^{37}$ APL, AmL 1918-1939, sygn. 503 Pismo Magistratu m. Torunia z 4 października 1924 r., k. 3; Pismo Magistratu m. Wadowic z 23 marca 1926 r., k. 95.

${ }^{38}$ Rozporządzenie Prezydenta Rzeczypospolitej z dnia 24 listopada 1927 r. o ubezpieczeniu pracowników umysłowych, Dz. U. Nr 106, poz. 911.

${ }^{39}$ APL, AmL 1918-1939, sygn. 435, Pismo Ministra Spraw Wewnętrznych do Wojewody Lubelskiego $z$ dnia 16 kwietnia 1929 r. w sprawie statutów emerytalnych pracowników związków komunalnych; SŁowiŃsKI, Kancelaria miasta, s. 99.

40 APL, AmL 1918-1939, sygn. 435, Wycinek artykutu o emeryturach pracowników Magistratu m. Lublina, k. 39.

${ }^{41}$ Tamże.
} 
pracownikom, tj. zarówno umysłowym jak, i fizycznym, na zasadach określonych w ustawie z dnia 11 grudnia 1923 r. o zaopatrzeniu emerytalnym funkcjonariuszów państwowych $^{42}$. Ubezpieczeniem zostali objęci wszyscy pracownicy zatrudnieni na podstawie nominacji lub najmu usług, zarówno w dziale administracji ogólnej, jak i w przedsiębiorstwach miejskich, a także w instytucjach i zakładach utrzymywanych przez samorząd miejski. Ubezpieczenie nie obejmowało natomiast pracowników sezonowych. Na podstawie niniejszej uchwały, pracownikom którzy mieli za sobą przynajmniej 5 lat służby w Magistracie m. Lublina, w razie nabycia uprawnień emerytalnych, doliczano do wymiaru emerytury lata ich poprzedniej służby samorządowej lub państwowej, względnie pracy zawodowej, tak jak było to przewidziane w odniesieniu do funkcjonariuszy państwowych. Wzorując się na rozwiązaniach ustawy o zaopatrzeniu emerytalnym funkcjonariuszów państwowych, w celu utworzenia funduszu emerytalnego, Rada Miejska poleciła Magistratowi pobierać od pracowników składki w wysokości 3\% całkowitego uposażenia, wypłacanego z funduszów miejskich drogą potrącenia, przy czym składki za okres od 1-ego stycznia do 1-ego października 1928 r. pokrył Magistrat. Zebrane kwoty na fundusz emerytalny były lokowane w Banku Gospodarstwa Krajowego na specjalnym rachunku. Niniejsze przepisy obowiązywały z datą wsteczną, tj. od 1 stycznia 1928 r. $^{43}$

Prace nad przepisami emerytalnymi pracowników samorządowych zakończyły się uchwaleniem Statutu o zaopatrzeniu emerytalnym pracowników komunalnych m. Lublina i ich rodzin z 29 lipca 1930 r., z mocą obowiązującą od 1 sierpnia tego roku $^{44}$. W rozwiązaniach wiernie odzwierciedlał postanowienia wzorowego statutu o zaopatrzeniu pracowników komunalnych i ich rodzin, opracowanego wówczas przez Ministerstwo Spraw Wewnętrznych i rozesłanego wojewodom z zaleceniem wcielenia go w życie przez poszczególne związki samorządowe ${ }^{45}$.

${ }^{42}$ Ustawa z dnia 11 grudnia 1923 r. o zaopatrzeniu emerytalnym funkcjonariuszów państwowych, Dz. U. z 1924 r. Nr 6, poz. 46; APL, AmL 1918-1939, sygn. 435, Odpis uchwaty Rady Miejskiej m. Lublina z dnia 22 listopada 1928 r., k. 77; Odpis uchwaty Magistratu nr 1386 w sprawie ubezpieczenia emerytalnego pracowników nieetatowych wydziałów administracyjnych oraz pracowników instytucji autonomicznych, k. 51.

${ }^{43}$ Tamże. APL, AmL 1918-1939, sygn. 435, Odpis uchwaty Rady Miejskiej m. Lublina z dnia 22 listopada 1928 r., k. 77.

${ }^{44}$ Dziennik Zarządu m. Lublina nr 5 i 6 z 1 sierpnia 1930 r., Statut o zaopatrzeniu emerytalnym pracowników komunalnych $m$. Lublina i ich rodzin z 29 lipca 1930 r., s. 757-766 [dalej cyt.: Statut o zaopatrzeniu emerytalnym z 1930 r.].

45 APL, AmL 1918-1939, sygn. 435, Okólnik Ministra Spraw Wewnętrznych nr 148 z 18 lipca 1929 w sprawie statutu emerytalnego pracowników komunalnych, k. 167-169; Wzorowy statut o zaopatrzeniu emerytalnym pracowników komunalnych i ich rodzin, k. 170-179. 
Na mocy postanowień Statutu o zaopatrzeniu emerytalnym z 1930 r., gmina miasta Lublina wzięła na siebie obowiązek zaopatrzenia emerytalnego swoich pracowników i pozostałych po nich członków rodzin, szczegółowo określając zasady przyznawania świadczeń emerytalnych ${ }^{46}$. Pracownikami komunalnymi w rozumieniu niniejszego statutu byli: a) pracownicy Magistratu m. Lublina, zajmujący stanowiska przewidziane w statucie etatów stanowisk służbowych, b) pracownicy zakładów i przedsiębiorstw komunalnych, zajmujący stanowiska uznane za stałe przez statut danego przedsiębiorstwa, c) płatni członkowie Zarządu miasta Lublina, o ile pełnienie funkcji członków Zarządu miasta stanowiło ich główne zajęcie ${ }^{47}$. Podstawę wymiaru zaopatrzenia emerytalnego stanowiło całkowite uposażenie, pobierane ostatnio przez pracownika wraz ze wszystkimi stałymi dodatkami w gotówce, z wyłączeniem dodatku reprezentacyjnego, technicznego i ad personam ${ }^{48}$. Na pokrycie świadczeń przewidzianych w statucie utworzono fundusz emerytalny, który powstał z opłat pracowników pozostających w służbie czynnej, w wysokości 3\% ich poborów służbowych oraz dopłat miasta w wysokości $7 \%$ tych poborów ${ }^{49}$. Opłaty były potrącane przy każdorazowej wypłacie poborów miesięcznych ${ }^{50}$. W tym samym czasie dopłaty uiszczało również miasto ${ }^{51}$. Funduszem emerytalnym administrował Zarząd miasta, zaś zgromadzone na nim środki nie mogły być przeznaczone na inne cele ${ }^{52}$.

Prawo do zaopatrzenia emerytalnego nabywał pracownik komunalny z chwilą upływu co najmniej 10 lat służby, zaliczanych do wysługi emerytalnej ${ }^{53}$. Do wysługi emerytalnej wliczano czas służby w Magistracie m. Lublina od dnia jej

46 § 3 Statut o zaopatrzeniu emerytalnym z $1930 \mathrm{r}$.

47 Tamże, § 1. Przepisy Statutu nie miały zastosowania do: a) pracowników umysłowych przyjętych na służbę miejską na czas oznaczony lub wykonania określonej pracy, b) pracowników, którzy w myśl przepisów rozporządzenia Prezydenta Rzeczypospolitej Polski z dnia 24 listopada 1927 r. o ubezpieczeniu pracowników umysłowych, nie podlegali ubezpieczeniu, c) pracowników, którzy w myśl rozporządzenia Prezydenta Rzeczypospolitej Polski z dnia 24 listopada 1927 r. o ubezpieczeniu pracowników umysłowych, nie żądali zwolnienia od ubezpieczenia, d) pracowników, którzy rozpoczęli służbę miejską po przekroczeniu 55 lat.

48 § 4 Statutu o zaopatrzeniu emerytalnym z $1930 \mathrm{r}$.

49 Tamże, $\S 5$.

50 Tamże.

${ }^{51}$ Tamże.

52 Tamże, $\S 6$.

53 Tamże, $\S 10$. W pewnych wyjątkowych przypadkach pracownik nabywał prawo do emerytury nieco wcześniej, a mianowicie po 5 latach stałej służby, o ile z powodu kalectwa lub choroby nabytej bez własnej winy stał się trwale niezdolny do wykonywania zawodu. Bez względu na czas służby pracownik nabywał zaopatrzenie emerytalne, jeżeli stał się trwale niezdolny do wykonywania zawodu z powodu: a) nieszczęśliwego wypadku, wynikłego w czasie pełnienia obowiązków służbowych, b) choroby zawodowej, c) działań wojennych w miejscu służbowego pobytu, d) chorób zakaźnych, panujących w miejscu pobytu służbowego. 
rozpoczęcia oraz czas pracy u innych pracodawców, za który przekazano funduszowi emerytalnemu składki ${ }^{54}$. Zaliczeniu podlegał również czas czynnej służby w wojsku polskim oraz czas przebyty w niewoli, jeżeli dostanie się do niewoli nastąpiło bez winy pracownika ${ }^{55}$. Natomiast przy wymiarze zaopatrzenia emerytalnego doliczano czas obowiązkowej służby wojskowej, jak również minimalny czas studiów wyższych na jednym $\mathrm{z}$ uniwersytetów lub w równorzędnym zakładzie naukowym, zakończonych ustawowo przewidzianym egzaminem ${ }^{56}$.

Dodatkowo, zgodnie z brzmieniem $\S 14$, pracownikowi, który po co najmniej dziesięcioletniej służbie stał się trwałe niezdolny do pracy, a ponadto utracił bez własnej winy co najmniej 95\% zdolności do zarobkowania, doliczano do zaopatrzenia emerytalnego 10 lat do czasu służby, podlegającego normalnemu zaliczeniu do wysługi emerytalnej ${ }^{57}$.

Prawo do zaopatrzenia emerytalnego nie przysługiwało w przypadku utraty obywatelstwa polskiego oraz w razie wstąpienia do klasztoru. Wyłączeniu ulegali także emeryci, którym zapewniono całkowite utrzymanie w zakładzie leczniczym w związku z chorobą umysłową lub kalectwem ${ }^{58}$. Zaopatrzenie emerytalne po 10 latach służby, zaliczonej do wysługi emerytalnej, wynosiło $40 \%$ podstawy wymiaru i wzrastało z każdym następnym rokiem o 2,4\%, przy czym w żadnym wypadku nie mogło przekroczyć $100 \%$ podstawy wymiaru ${ }^{59}$.

Prawo do pobierania zaopatrzenia emerytalnego zasadniczo gasło $\mathrm{w}$ razie śmierci emeryta. Drugą przyczyną wygaśnięcia było prawomocne skazanie emeryta za czyn karygodny, gdy jednocześnie skazanie pociągało utratę zdolności do piastowania urzędu publicznego. Wobec tego, że przedstawione rozwiązanie dotykało rodzinę emeryta, Rada Ministrów mogła w tym przypadku przyznać żonie i dzieciom emeryta odpowiedni zasiłek na czas, przez który rodzina pozostawałaby bez środków utrzymania ${ }^{60}$.

${ }^{54} \S 11$ ust. 1 Statutu o zaopatrzeniu emerytalnym z 1930 r.; zob. W. DALBor, Zaliczenie lat poprzedniej stużby państwowej do wystugi emerytalnej pracowników samorządowych oraz płatnych członków magistratu b. dz. pr., „Samorząd” 24 (1934), s. 366-367.

$55 \S 11$ ust. 2 Statutu o zaopatrzeniu emerytalnym z $1930 \mathrm{r}$.

56 Tamże, ust. 3. Do wysługi emerytalnej nie wliczał się: a) czas służby, odbytej przed ukończeniem 18 roku życia, b) czas urlopu bez uposażenia, c) czas zawieszenia w służbie, d) czas odliczony na podstawie orzeczenia sądu dyscyplinarnego.

${ }^{57} \S 14$ Statut o zaopatrzeniu emerytalnym z $1930 \mathrm{r}$.

58 Tamże, $\$ 28$.

59 Tamże, § 19.

${ }^{60}$ Tamże, $\$ 27$. 


\section{UBEZPIECZENIA PRACOWNIKÓW ZARZĄDU M. LUBLINA WOBEC UNIFIKACJI SYTEMU UBEZPIECZEŃ SPOŁECZNYCH W KRAJU}

Ujednolicenie zasad ubezpieczeń społecznych nastąpiło za sprawą wejścia w życie ustawy z dnia 28 marca 1933 r. o ubezpieczeniu społecznym, zwanej powszechnie „ustawą scaleniową"61. Ustawa ta regulowała trzy typy ubezpieczeń społecznych: 1) na wypadek choroby i macierzyństwa; 2) na wypadek niezdolności do zarobkowania (względnie śmierci), powstałej na skutek wypadku przy pracy lub choroby zawodowej i 3) na wypadek niezdolności do zarobkowania, powstałej na skutek inwalidztwa pracownika fizycznego ${ }^{62}$. Rzeczonej ustawie podlegały wszystkie osoby bez różnicy płci i wieku, które pozostawały w stosunkach prawnych bądź w stosunkach służbowych. W tym miejscu należy wyjaśnić, jak wyglądała sytuacja ubezpieczeń pracowników samorządowych.

$\mathrm{Na}$ zasadzie ustawy scaleniowej pracownicy samorządowi zasadniczo podlegali ubezpieczeniu na wypadek choroby i macierzyństwa ${ }^{63}$. Jednakże na podstawie art. 297 ustawy scaleniowej, objęcie tym ubezpieczeniem pracowników instytucji, które przed wejściem w życie ustawy udzielały pomocy leczniczej zamiast ubezpieczania w Kasach Chorych, odroczono do terminu wyznaczonego przez Radę Ministrów $^{64}$. Zgodnie $\mathrm{z}$ brzmieniem dyspozycji tego przepisu, pracownicy samorządowi Lublina, jako korzystający z pomocy lekarskiej oferowanej przez Zarząd, nie podlegali temu ubezpieczeniu. Jednakże wejście w życie ustawy scaleniowej zobligowało władze miejskie do uchwalenia kolejnego statutu pomocy leczniczej, uwzględniającego rozwiązania rzeczonej ustawy ${ }^{65}$. Nowy Statut pomocy leczniczej został zatwierdzony na posiedzeniu Rady Miejskiej w dniu 25 czerwca 1935 r. i ujmował uprawnienia zawodowych członków Zarządu Miejskiego w Lublinie, pracowników miejskich i emerytów miejskich oraz ich rodzin na wypadek choroby i macierzyństwa ${ }^{66}$. Zakres świadczeń $w$ ramach oferowanej pomocy lekarskiej oraz krąg osób uprawnionych do korzystania z nich pozostał w zasadzie niezmieniony.

${ }^{61}$ Ustawa z dnia 28 marca 1933 r. o ubezpieczeniu społecznym, Dz. U. Nr 51, poz. 396 [dalej cyt.: ustawa scaleniowa].

${ }^{62}$ Z. Landau, Ubezpieczenia społeczne w Polsce w latach kryzysu gospodarczego 1930-1935, „Praca i Zabezpieczenie Społeczne” 10-11 (1968), s. 41-42.

${ }^{63}$ W. Dulinicz, Ustawa scaleniowa a ubezpieczenia pracowników samorządowych, „Samorząd” 6 ( 1934), s. 81.

${ }^{64}$ T. DyвоsкI, Ubezpieczenia społeczne w Polsce w ostatnich latach, Warszawa: Instytut Spraw Społecznych 1939, s. 7-10.

${ }^{65}$ Dulinicz, Ustawa scaleniowa, s. 81-82.

${ }^{66}$ APL, AmL 1918-1939, sygn. 401, Statutu pomocy leczniczej dla zawodowych członków Zarządu Miejskiego, pracowników miejskich i emerytów miejskich z 25 czerwca 1935 r., k. 25-32 [dalej cyt.: Statut pomocy leczniczej dla zawodowych członków Zarządu z 1935 r.]. 
Skróceniu do 13 tygodni uległ okres niezdolności do pracy z powodu choroby, w czasie którego pracownik był uprawniony do pobierania uposażenia ${ }^{67}$. Okres ten mógł być przedłużony do 26 tygodni na podstawie orzeczenia Komisji Lekarskiej $^{68}$. Na pokrycie świadczeń określonych w Statucie przewidziano utworzenie specjalnego Funduszu Pomocy Leczniczej, który miał składać się przede wszystkim ze składek opłacanych przez pracodawcę (w wysokości 2,3\% od uposażenia pracowników umysłowych i 2,5\% od uposażenia pracowników fizycznych) oraz kwot $\mathrm{z}$ uposażeń ubezpieczonych w wysokości 1,5\% ich uposażeń ${ }^{69}$. Pomoc lekarska oferowana przez Zarząd Miejski dla pracowników miejskich przestała być w pełni nieodpłatna.

W związku z trwającymi pracami legislacyjnymi nad projektami ustaw pracowniczych oraz wobec tego, że projekty te miały uregulować również kwestie ubezpieczenia pracowników miejskich, Ministerstwo Spraw Wewnętrznych na mocy wydanego w dniu 15 kwietnia 1936 r. Okólnika, zakazało władzom nadzorczym związków samorządowych zatwierdzania statutów dotyczących ubezpieczenia chorobowego i emerytalnego ${ }^{70}$. Wojewoda Lubelski powołując się na powyżej wskazany Okólnik pismem z dnia 6 maja 1936 r., zwrócił bez załatwienia przedłożony przez Magistrat Statut pomocy leczniczej dla zawodowych członków Zarządu miejskiego z $1935 \mathrm{r}^{71}$

W odniesieniu do ubezpieczenia emerytalnego, to nie obejmowało ono wszystkich pracowników samorządowych. Zgodnie z art. 6 ustawy scaleniowej, pracownicy umysłowi, objęci rozporządzeniem z 24 listopada 1927 r. o ubezpieczeniu pracowników umysłowych bądź zwolnieni od ubezpieczeń na mocy powyższego rozporządzenia, nie podlegali ubezpieczeniu emerytalnemu, określonego ustawą scaleniową $^{72}$. W stosunku do pracowników samorządowych moc obowiązującą zachowały dotychczas obowiązujące statuty emerytalne ${ }^{73}$. Pracownicy samorządowi Magistratu m. Lublina podlegali przepisom obowiązującego Statutu o zaopatrzeniu emerytalnym z 1930 r. Ustawa scaleniowa nie zawiera podobnego zwolnienia w od-

\footnotetext{
${ }^{67} \S 11$ ust. 1 Statutu pomocy leczniczej dla zawodowych członków Zarządu z 1935 r.

68 Tamże.

69 Tamże, § 22 ust. 2.

${ }^{70}$ Okólnik Ministerstwa Spraw Wewnętrznych nr 24 z 15 kwietnia 1936 r. o ubezpieczeniach chorobowych i emerytalnych w samorządzie terytorialnym, Dz. Urz. M. S. W. Nr 11, poz. 64.

${ }^{71}$ APL, AmL 1918-1939, sygn. 401, Pismo Lubelskiego Urzędu Wojewódzkiego z 6 maja 1936 r. do Prezydenta miasta Lublina, k. 23.

${ }^{72}$ Zob. S. ZAKrZEwski, Niebezpieczeństwo emerytalne w samorzadach, „Samorząd” 16 (1935), s. 262; J. ChYLEwSKI, Jak rozwiązać problem emerytalny w samorządzie terytorialnym, „Samorząd” 46 (1935), s. 710-711.

${ }^{73}$ W. KARPIŃSKI, Ubezpieczenie emerytalne pracowników samorządowych, „Samorząd” 35 (1935), s. 537-538.
} 
niesieniu do fizycznych pracowników samorządowych. Zostali oni objęci ustawą w zakresie ubezpieczenia emerytalnego i w związku z tym podlegali obowiązkowi zgłoszenia do Zakładu Ubezpieczenia Emerytalnego Robotników. Doprowadziło to do powstania swoistego rodzaju dwutorowości rozwiązań prawnych. Dotychczas uchwalane przepisy ubezpieczeniowe dla pracowników samorządowych nie czyniły różnicy między pracownikami fizycznymi a umysłowymi. Kwestią determinującą zasady podlegania pracowników ubezpieczeniu była stałość zatrudnienia ${ }^{74}$.

Trzeci typ ubezpieczenia, uregulowany ustawą scaleniową, czyli ubezpieczenie wypadkowe, obejmowało wszystkich pracowników samorządowych. Jednakże ubezpieczenia te w odniesieniu do stałych pracowników samorządowych były uregulowane przez związki samorządowe we własnym zakresie w drodze wydawanych statutów emerytalnych ${ }^{75}$.

\section{PODSUMOWANIE}

Analiza zasad ubezpieczania pracowników samorządowych międzywojennego Lublina ukazuje, jak trudnym i żmudnym zadaniem było stworzenie jednolitego systemu ubezpieczeń społecznych w odradzającym się państwie. Należało bowiem nie tylko ujednolicić ustawodawstwo pozaborcze, ale przede wszystkim dostosować je do warunków społeczno-politycznych niepodległego kraju. Zadania tego nie ułatwiała również postawa samorządów, odmawiających zgłaszania swych pracowników do nowo powstających instytucji ubezpieczeniowych, czego dowodzi chociażby wieloletni spór Magistratu m. Lublina z Powiatową Kasą Chorych w Lublinie. Ujednolicenie zasad ubezpieczeń społecznych nastąpiło dopiero za sprawą wejścia w życie ustawy scaleniowej z 1933 r.

Pomimo uchwalenia jednolitych norm prawnych w zakresie ubezpieczeń społecznych samorządy terytorialne na mocy obowiązujących przepisów miały prawo samookreślania warunków uzyskiwania świadczeń pomocy lekarskiej oraz zabezpieczenia emerytalnego w drodze wydawanych statutów wewnętrznych. W związku z powyższym można mówić o swoistego rodzaju partykularyzmie prawnym systemu ubezpieczeń pracowników samorządowych w II Rzeczypospolitej, gdyż miasta posiadały odrębne uregulowania prawne w zakresie szczegółowej organizacji i funkcjonowania ubezpieczeń swych pracowników, mieszczące się oczywiście

\footnotetext{
${ }^{74}$ Dulinicz, Ustawa scaleniowa, s. 81.

${ }^{75}$ Dyвоsкi, Ubezpieczenia społeczne, s. 10.
} 
w granicach delegacji ustawowej. Posiadanie własnych uregulowań pozbawiło niejako stosunki ubezpieczeniowe charakteru publiczno-prawnego ${ }^{76}$.

\section{BIBLIOGRAFIA}

\section{ŹRÓDŁA PRAWA}

Dekret z dnia 11 stycznia 1919 r. o obowiązkowym ubezpieczeniu na wypadek choroby, Dz. Pr. P. P. $\mathrm{Nr}$ 9, poz. 122.

Okólnik Ministerstwa Spraw Wewnętrznych nr 24 z 15 kwietnia 1936 r. o ubezpieczeniach chorobowych i emerytalnych w samorządzie terytorialnym, Dz. Urz. M. S. W. Nr 11, poz. 64.

Rozporządzenie Prezydenta Rzeczypospolitej z dnia 24 listopada 1927 r. o ubezpieczeniu pracowników umysłowych, Dz. U. Nr 106, poz. 911.

Ustawa z dnia 20 maja 1920 r. o obowiązkowym ubezpieczeniu na wypadek choroby, Dz. U. Nr 44, poz. 272.

Ustawa z dnia 11 grudnia 1923 r. o zaopatrzeniu emerytalnym funkcjonariuszów państwowych, Dz. U. z 1924 r. Nr 6, poz. 46.

Ustawa z dnia 28 marca 1933 r. o ubezpieczeniu społecznym, Dz. U. Nr 51, poz. 396.

\section{ŹRÓDŁA DRUKOWANE}

Dziennik Zarządu m. Lublina nr 5 i 6 z 1 sierpnia 1930 r.

Dziennik Zarządu m. Lublina nr 9 i 10 z 21 października 1930 r.

\section{ARCHIWALIA}

Archiwum Państwowe w Lublinie, zespół Akta m. Lublina 1915-1918, sygn. 9.

Archiwum Państwowe w Lublinie, zespół Akta m. Lublina 1918-1939, sygn. 401, 435, 503.

\section{LITERATURA}

[brak informacji o Autorze] O ubezpieczeniu społecznym w Polsce, Praca i Opieka Społeczna 1 (1923), s. 35-53.

CHYlewski Jerzy: Jak rozwiązać problem emerytalny w samorządzie terytorialnym, Samorząd 46 (1935), s. 710-712.

DALBOR Władysław: Zaliczenie lat poprzedniej służby państwowej do wysługi emerytalnej pracowników samorządowych oraz płatnych członków magistratu b. dz. pr., Samorząd 24 (1934), s. 366-367.

Dulinicz Wacław: Charakter prawny ubezpieczenia emerytalnego pracowników samorządowych, Samorzą 28 (1934), s. 426-428.

Dulinicz Wacław: Ustawa scaleniowa a ubezpieczenia pracowników samorządowych, Samorząd 6 (1934), s. 81-82.

${ }^{76}$ W. DuLINICZ, Charakter prawny ubezpieczenia emerytalnego pracowników samorzadowych, „Samorząd” 28 (1934), s. 427. 
Dyвоsкi Tadeusz: Ubezpieczenia społeczne w Polsce w ostatnich latach, Warszawa: Instytut Spraw Społecznych 1939.

Historia państwa i prawa Polski 1918-1939, cz. II, red. F. Ryszka, Warszawa: Polskie Wydawnictwo Naukowe 1968.

JAKUBIEC Dariusz: Pierwsze polskie instytucje ubezpieczeń społecznych. Zarys historii i ustroju, Warszawa: Zakład Ubezpieczeń Społecznych 2007.

KARPIŃSKI W.: Ubezpieczenie emerytalne pracowników samorządowych, Samorząd 35 (1935), s. 536-539.

KorCZAK Jerzy: Sytuacja prawna pracowników samorządowych w II i III Rzeczypospolitej, [w]: 20 lat samorządu terytorialnego w II i III Rzeczypospolitej, red. J. Korczak, Wrocław: Kolonia Limited 2010, s. 379-404.

Кововошicz Artur, Wiткоwsкi Wojciech: Historia ustroju i prawa polskiego (1772-1918), Kraków: Zakamycze 2001.

LANDAU Zbigniew: Ubezpieczenia społeczne w Polsce w latach kryzysu gospodarczego 1930-1935, Praca i Zabezpieczenie Spoleczne 10-11 (1968), s. 36-47.

Makarzec Piotr: Ubezpieczenia społeczne w II Rzeczypospolitej, Zeszyty Naukowe WSEI, seria Administracja 2 (2012), s. 197-210.

MusZALSKi Wojciech: Ubezpieczenia społeczne. Zarys ogólny, cz. 1, Warszawa: Zakład Ubezpieczeń Społecznych 1984.

SADOwsKa Jolanta: Prawnoorganizacyjne podstawy ubezpieczenia na wypadek choroby w Polsce, Studia i Materiały z Historii Ubezpieczeń Społecznych w Polsce 9 (1993), s. 17-55.

SŁOwiŃSKI Konrad: Kancelaria miasta Radomia w latach 1915-1939, Lublin: Wydawnictwo KUL 2016. SzUBERT Wacław: Stulecie polskich instytucji ubezpieczenia społecznego, Studia i Materiaty z Historii Ubezpieczeń Społecznych w Polsce 7 (1989), s. 5-10.

WraTnY Jerzy: Organizacja ubezpieczeń Społecznych, [w]: Rozwój ubezpieczeń społecznych w Polsce, red. C. Jackowiak, Wrocław: Zakład Narodowy im. Ossolińskich, Wydawnictwo Polskiej Akademii Nauk 1991, s. 53-67.

ZAKRZEwSKi Stanisław: Niebezpieczeństwo emerytalne w samorządach, Samorząd 16 (1935), s. 262263.

ZIELIŃSKI Tadeusz: Ubezpieczenia społeczne pracowników. Zarys systemu prawnego - część ogólna, Warszawa-Kraków: Wydawnictwo Naukowe PWN 1994.

\section{UBEZPIECZENIA SPOŁECZNE PRACOWNIKÓW MIEJSKICH ZARZĄDU MIASTA LUBLINA W LATACH 1918-1939}

\section{Streszczenie}

Na ziemiach polskich po odzyskaniu niepodległości istniały różne systemy prawne odziedziczone po zaborcach. Odmienny stan prawny obowiązywał także w dziedzinie ubezpieczeń społecznych. Stworzenie jednolitego systemu ubezpieczeń społecznych w odradzającym się państwie było bardzo trudnym zadaniem. Należało bowiem nie tylko ujednolicić ustawodawstwo pozaborcze, ale przede wszystkim dostosować je do warunków społeczno-politycznych niepodległego kraju. Ujednolicenie zasad ubezpieczeń społecznych nastąpiło za sprawą wejścia w życie ustawy z dnia 28 marca $1933 \mathrm{r}$. o ubezpieczeniu społecznym, zwanej powszechnie ,ustawą scaleniową”. Analiza zasad ubezpieczania pracowników samorządowych międzywojennego Lublina pokazuje, że mimo uchwalenia jednolitych norm prawnych w zakresie ubezpieczeń społecznych, samorządy terytorialne, a właściwie organy 
samorządowe, na mocy obowiązujących przepisów miały prawo samookreślania warunków uzyskiwania świadczeń pomocy lekarskiej oraz zabezpieczenia emerytalnego w drodze wydawanych statutów wewnętrznych, co prowadziło do swoistego rodzaju partykularyzmu prawnego systemu ubezpieczeń pracowniczych.

Słowa kluczowe: Magistrat miasta Lublina; ubezpieczenie emerytalne; ubezpieczenie chorobowe; pomoc lekarska; Kasa Chorych

\section{SOCIAL INSURANCE FOR MUNICIPAL EMPLOYEES \\ OF THE LUBLIN CITY COUNCIL IN YEARS 1918-1939}

\section{Sum mary}

After Poland regained independence, it operated within various legal systems inherited from the partitioning states. A different legal status was also in force in the field of social security. Establishing a unified social security system in a recovering state was a very difficult task. It was necessary not only to standardize post-partition legislation, but above all, to adapt it to the socio-political conditions of an independent country. The unification of social security rules took place due to the entry into force of the Act on social insurance of 28 March 1933, commonly referred to as "the merger act". The analysis of the principles of insuring municipal employees of the interwar Lublin reveals that, despite the adoption of uniform legal standards in the field of social security, local governments, or rather local government bodies, had the right under the applicable provisions to self-determine the conditions for obtaining medical assistance and retirement insurance by issuing internal statutes, which led to a kind of particularism of the legal employee insurance system.

Key words: the Lublin city municipality; retirement pension insurance; health insurance; medical assistance; Health Maintenance Organisation 